\title{
The influence of visual ability on learning and memory performance in 13 strains of mice
}

\author{
Richard E. Brown ${ }^{1}$ and Aimée A. Wong \\ Department of Psychology and Neuroscience Institute, Dalhousie University, Halifax, Nova Scotia, Canada, B3H 4J1
}

\begin{abstract}
We calculated visual ability in 13 strains of mice [129SI/Svlm], A/], AKR/], BALB/cBy], C3H/He], C57BL/6), $\mathrm{CAST} / \mathrm{Ei}$ ], DBA/2], FVB/N], MOLF/Ei], SJL/], SM/], and SPRET/Ei]) on visual detection, pattern discrimination, and visual acuity and tested these and other mice of the same strains in a behavioral test battery that evaluated visuo-spatial learning and memory, conditioned odor preference, and motor learning. Strain differences in visual acuity accounted for a significant proportion of the variance between strains in measures of learning and memory in the Morris water maze. Strain differences in motor learning performance were not influenced by visual ability. Conditioned odor preference was enhanced in mice with visual defects. These results indicate that visual ability must be accounted for when testing for strain differences in learning and memory in mice because differences in performance in many tasks may be due to visual deficits rather than differences in higher order cognitive functions. These results have significant implications for the search for the neural and genetic basis of learning and memory in mice.
\end{abstract}

Genetically modified mice have become the most commonly used subjects in the study of the molecular and cellular mechanisms underlying learning and memory processes (Wolfer et al. 1998; Nguyen and Gerlai 2002; Tonegawa et al. 2003; Mineur et al. 2004; Josselyn 2005). Transgenic and knockout mice have the phenotypic traits of the background strain, and differences between inbred strains, which are independent of the gene of interest, may significantly affect the behavioral phenotype of a mouse. For this reason, it is important to examine phenotypic differences between inbred strains of mice used as background strains for transgenic mice (Gerlai 1996; Tarantino et al. 2000; Nguyen and Gerlai 2002; Bothe et al. 2005; Brooks et al. 2005).

Strain differences between inbred mice have been reported in learning in the Morris water maze (Upchurch and Wehner 1988; Holmes et al. 2002; Brooks et al. 2005), visual discrimination learning (Brooks et al. 2005), motor learning on the Rotarod (Tarantino et al. 2000; Bothe et al. 2005; Nadler et al. 2006), olfactory learning (Schellinck et al. 2001), habituation in an open field (Bothe et al. 2005), contextual and cued fear conditioning (Holmes et al. 2002; Bothe et al. 2005), social transmission of food preference (Holmes et al. 2002), lever-press escape/ avoidance (Brennan 2004), and object recognition memory (Sik et al. 2003, Brooks et al. 2005) as well as on tasks that measure anxiety and depression related behavior (van Gaalen and Steckler 2000; Voikar et al. 2001; Kim et al. 2002).

It is hypothesized that these strain differences in behavior are due to genetic influences on neural development, and reflect strain differences in the neuroanatomical, neurochemical, cellular, and molecular substrates associated with these behaviors. Strain differences have been observed in brain weight and size (Wahlsten et al. 2006); hippocampal morphology (Guillot et al. 1994; Abusaad et al. 1999; Peirce et al. 2003); corpus callosum anatomy (Wahlsten et al. 2003); cerebellar foliation patterns (Wahlsten and Andison 1991); monoamine neurochemistry (Mhyre et al. 2005); noradrenaline, choline, and GABA uptake (Schoemaker et al. 1982); hippocampal (Nguyen et al. 2000) and amygdalar long-term potentiation (LTP) (Schimanski and

\section{${ }^{1}$ Corresponding author.}

E-mail rebrown@dal.ca; fax (902) 494-6585.

Article is online at http://www.learnmem.org/cgi/doi/10.1101/lm.473907.
Nguyen 2005); and gene expression patterns in multiple brain regions (Fernandes et al. 2004; Nadler et al. 2006).

However, strain differences in learning and memory performance may be due to differences in sensory abilities between strains. Many mouse strains have hearing deficits (Jones et al. 2006), while others have deficits in visual ability (Chang et al. 2002; Wong and Brown 2006b). If it is to be demonstrated that strain differences in learning and memory performance are due to differences in cognitive functions, it must be shown that these differences are not confounded by strain differences in sensory function (Crawley 1999; Bailey et al. 2006).

Sixteen naturally occurring gene mutations that cause degeneration of the photoreceptors in the retina have been identified and these mutations occur in 52 strains of mice (Chang et al. 2002). Many strains of mice with retinal degeneration are currently used as background strains for animal models of neurodegenerative disorders in experiments aimed at unraveling the neural and genetic basis of learning and memory. For example, FVB/ $\mathrm{N}, \mathrm{C} 57 \mathrm{BL} / 6, \mathrm{BALB} / \mathrm{c}$, and $\mathrm{C} 3 \mathrm{H}$ mice are often used as embryo donors for the creation of transgenic mice (Yoshiki and Moriwaki 2006); however, FVB/N and C3H mice suffer from the Pde6b allele on chromosome 5 , which causes the retinal degeneration 1 mutation; BALB/c mice have poor vision due to albinism; and C57BL/6J mice have age-related deafness (McFadden et al. 2001).

Previously, we have shown that the 14 strains of mice most commonly used in behavioral studies have significant differences in visual ability (Wong and Brown 2006b). At 3-6 mo of age, some strains have "good" vision (129SI/Sv1mJ, C57BL/6J, and $\mathrm{DBA} / 2 \mathrm{~J})$; albino strains have poorer vision $(\mathrm{A} / \mathrm{J}, \mathrm{BALB} / \mathrm{cByJ}$, $\mathrm{BALB} / \mathrm{CJ}$ ), except for $\mathrm{AKR} / \mathrm{J}$, whose vision is as good as mice with normal vision. Strains with retinal degeneration are functionally blind $(\mathrm{C} 3 \mathrm{H} / \mathrm{HeJ}, \mathrm{FVB} / \mathrm{NJ}, \mathrm{MOLF} / \mathrm{EiJ}, \mathrm{SJL} / \mathrm{J})$ and other strains whose visual physiology is unknown (CAST/Ei, SM/J, and SPRET/ Ei) also appear to have poor vision (Wong and Brown 2006b). In addition, DBA/2J mice have age-related blindness due to a condition that resembles pigmentary glaucoma in humans (Anderson et al. 2002; Moon et al. 2005; Zhou et al. 2005) and are functionally blind by 12 mo of age (Wong and Brown 2006a).

In order to measure higher order cognitive processes, such as learning and memory, mice must be tested in behavioral tasks such as the Morris water maze. Although many investigators 
have suggested that performance of mice in behavioral tasks may depend on visual ability (Robinson et al. 2001; Voikar et al. 2001; Carman and Mactutus 2002; Thifault et al. 2002; Brooks et al. 2005; Clapcote et al. 2005a,b), these warning have gone unheeded as many researchers have used visually impaired mice in visuo-spatial tasks, such as the Morris water maze. In this article, therefore, we examined the effects of strain differences in visual ability in three different learning and memory tasks: the Morris water maze hidden and visible platform tasks, an olfactory discrimination task, and the Rotarod.

The Morris water maze was developed to measure spatial learning and memory in rats (Morris 1984) and has been adapted for use with mice. It is one of the most common behavioral paradigms for evaluating the neural (Royle et al. 1999; D'Hooge and De Deyn 2001) and genetic basis of learning (Steinberger et al. 2003). The Morris water maze relies on visual information because the mouse must use extramaze visuo-spatial cues to orient itself and locate the hidden platform. The visible platform task is often used to control for visual ability in the water maze, but the intramaze visual cues that signal the platform location are closer than the extramaze visual cues. Therefore, it has been argued that the visual platform test is not an adequate measure of visual ability (Prusky et al. 2000b) as the visible platform test measures gross visual impairments rather than slight differences in visual acuity that may affect the detection of distal extramaze cues (Robinson et al. 2001).

The conditioned odor preference task developed by Schellinck et al. $(2001,2004)$ trains animals to dig in wood shavings associated with one odor to obtain sugar reward and to associate wood shavings paired with a second odor with no reward. Mice are then given a preference test to determine which of the two odors elicits the most digging behavior. Mice of three strains (CD1, C57Bl/6NCr/BR, and DBA/2NCr/BR) have been shown to learn this task (Schellinck et al. 2001), and we have shown that both C57BL/6J and DBA/2J mice can perform this task between 12 and 24 mo of age (Wong and Brown 2006a). The accelerating Rotarod measures motor-coordination and motor learning over a number of days. Mice can learn this task (McFadyen et al. 2003), but the rate of learning and maximal performance in many strains is confounded by body weight (Brown et al. 2002).

Our aim in this article, therefore, is to quantitatively examine the effects of strain differences in visual ability on performance in a visuo-spatial task, (the Morris water maze) and two nonvisual-spatial tasks: conditioned odor preference and motor learning on the Rotarod.

\section{Materials and Methods}

\section{Subjects}

Mice of 13 different strains were obtained from the Jackson Laboratory (Bar Harbour, ME) under the aegis of the JAX Phenome project when they were $\sim 8$ wk of age. Table 1 gives information on the number of male and female mice of each strain tested in each behavioral task and the JAX Phenome project information on each strain. Mice were individually housed in clear, plastic cages $(18.75 \times 28 \times 12.5 \mathrm{~cm})$ with wood shavings for bedding and were fed Purina rodent chow (no. 5001) and water ad libitum. The colony room was on a reversed 12:12 h light:dark cycle (lights off at 9:00 am) and maintained at a constant temperature $\left(22^{\circ} \mathrm{C} \pm 2^{\circ} \mathrm{C}\right)$. All mice were $\sim 16$ wk of age when testing began and were weighed on an Ohaus Scout II digital scale at the beginning of each behavioral task. Mice were always tested in the dark phase of the light:dark cycle. Mice were tested in the visual detection, pattern discrimination, and visual acuity tasks (16-20 wk of age); the Morris water maze (21 wk of age); conditioned odor preference task (22 wk of age); and the Rotarod (23 wk of age) in that order. Mice were treated in accordance with the regulations set forth by the Canada Council on Animal Care, and the experimental protocol was approved by the Dalhousie University Committee on Animal Care.

\section{Vision tests}

Visual ability was tested using the visual water box as described by Wong and Brown (2006a,b). This was a trapezoidal-shaped pool $(80 \mathrm{~cm}$ wide $\times 140 \mathrm{~cm}$ long $\times 55 \mathrm{~cm}$ high) filled with room temperature tap water $\left(22^{\circ} \mathrm{C}\right)$. The pool was wider at one end $(80$ $\mathrm{cm}$ ) than the other $(25 \mathrm{~cm})$, and the wide end contained a release chute $(35 \times 7 \times 20 \mathrm{~cm})$ and a 41-cm-long midline divider $(40$ $\mathrm{cm}$ high). Visual stimuli were displayed on two identical 17-inch $(43.2 \mathrm{~cm})$ computer-controlled monitors (Accu Sync $70 \mathrm{Nec} 3$ ) that were placed next to each other at the wide end of the pool. An escape platform $(37 \times 13 \times 14 \mathrm{~cm})$ was placed below the positive visual stimulus computer screen, and the screen reflections made the hidden platform invisible from water level. Sinusoidal gratings ( $\sim 4 \mathrm{~cm}$ wide) were used as visual stimuli and were formed by gradual sine-wave variations in luminance. The spatial frequencies of the gratings were measured in cycles/degree (c/ deg) and were restricted to those with full cycles to ensure that the mean luminance between the screens did not differ. Spatial frequency measurements refer to the gratings as seen from the end of the divider ( $41 \mathrm{~cm}$ from the computer screen). The homogeneous gray screen was generated by setting the contrast level to zero.

Mice were tested in four phases: pretraining, visual detection, pattern discrimination, and visual acuity as described by

Table 1. Number of male (M) and female (F) mice of each strain that completed each behavioral task

\begin{tabular}{|c|c|c|c|c|c|c|c|}
\hline Strain & JAX stock no. & Type & MPD group & $\begin{array}{l}\text { No. of mice tested } \\
\text { in all three } \\
\text { vision tasks }\end{array}$ & $\begin{array}{l}\text { No. of mice tested } \\
\text { in the Morris } \\
\text { water maze }\end{array}$ & $\begin{array}{l}\text { No. of mice tested } \\
\text { in the conditioned } \\
\text { odor preference task. }\end{array}$ & $\begin{array}{l}\text { No. of mice tested } \\
\text { on the Rotarod }\end{array}$ \\
\hline 129S1/SvImJ & 002448 & IN & A & $6 \mathrm{M}, 2 \mathrm{~F}$ & 7M, 7F & $9 \mathrm{M}, 9 \mathrm{~F}$ & $12 \mathrm{M}, 12 \mathrm{~F}$ \\
\hline$A / J$ & 000646 & IN & A & $10 \mathrm{M}, 5 \mathrm{~F}$ & $18 \mathrm{M}, 6 \mathrm{~F}$ & $18 \mathrm{M}, 17 \mathrm{~F}$ & $18 \mathrm{M}, 12 \mathrm{~F}$ \\
\hline AKR/I & 000648 & IN & B & $6 \mathrm{M}$ & $12 \mathrm{M}, 12 \mathrm{~F}$ & $12 \mathrm{M}, 12 \mathrm{~F}$ & $12 \mathrm{M}, 12 \mathrm{~F}$ \\
\hline $\mathrm{BALB} / \mathrm{cBy}$ & 001026 & IN & A & $6 \mathrm{M}, 4 \mathrm{~F}$ & $6 \mathrm{M}, 15 \mathrm{~F}$ & $10 \mathrm{M}, 17 \mathrm{~F}$ & $12 \mathrm{M}, 21 \mathrm{~F}$ \\
\hline $\mathrm{C} 3 \mathrm{H} / \mathrm{Hel}$ & 000659 & IN & A & $8 \mathrm{M}, 7 \mathrm{~F}$ & $10 \mathrm{M}, 9 \mathrm{~F}$ & $9 \mathrm{M}, 11 \mathrm{~F}$ & $10 \mathrm{M}, 10 \mathrm{~F}$ \\
\hline C57BL/6] & 000664 & IN & A & $14 \mathrm{M}, 8 \mathrm{~F}$ & $11 \mathrm{M}, 8 \mathrm{~F}$ & $11 \mathrm{M}, 4 \mathrm{~F}$ & $17 \mathrm{M}, 14 \mathrm{~F}$ \\
\hline CAST/Ei] & 000928 & WD & A & $6 \mathrm{M}, 4 \mathrm{~F}$ & $11 \mathrm{M}, 10 \mathrm{~F}$ & $9 \mathrm{M}, 12 \mathrm{~F}$ & - \\
\hline $\mathrm{DBA} / 2$ & 000671 & IN & A & $6 M^{\prime} 10 F$ & $6 \mathrm{M}, 6 \mathrm{~F}$ & $12 \mathrm{M}, 12 \mathrm{~F}$ & $12 \mathrm{M}, 12 \mathrm{~F}$ \\
\hline FVB/NJ & 001800 & IN & A & $6 \mathrm{M}, 6 \mathrm{~F}$ & $6 \mathrm{M}, 6 \mathrm{~F}$ & $14 \mathrm{M}, 14 \mathrm{~F}$ & $12 \mathrm{M}, 12 \mathrm{~F}$ \\
\hline MOLF/EiJ & 000550 & WD & B & $7 \mathrm{M}, 8 \mathrm{~F}$ & $5 \mathrm{M}, 9 \mathrm{~F}$ & $11 \mathrm{M}, 11 \mathrm{~F}$ & $12 \mathrm{M}, 11 \mathrm{~F}$ \\
\hline SJL/J & 000686 & IN & A & $9 \mathrm{M}, 6 \mathrm{~F}$ & $12 \mathrm{M}, 12 \mathrm{~F}$ & $12 \mathrm{M}, 12 \mathrm{~F}$ & $12 \mathrm{M}, 12 \mathrm{~F}$ \\
\hline $\mathrm{SM} / \mathrm{J}$ & 000687 & IN & B & $9 \mathrm{M}, 7 \mathrm{~F}$ & $12 \mathrm{M}, 8 \mathrm{~F}$ & $12 \mathrm{M}, 10 \mathrm{~F}$ & $12 \mathrm{M}, 10 \mathrm{~F}$ \\
\hline SPRET/EiJ & 001146 & WD & A & $10 \mathrm{M}$ & $12 \mathrm{M}$ & - & - \\
\hline
\end{tabular}

Information from the JAX phenome project, showing the JAX stock number, whether the mouse is inbred (IN) or wild-derived (WD) and mouse phenome database priority (MPD) group (A or B). 
Wong and Brown (2006a,b). In the pretraining phase, mice were gradually shaped over 12 trials to associate the hidden platform located below the S+ screen (grating of $0.17 \mathrm{c} / \mathrm{deg}$ ) with escape. The divider separated the $\mathrm{S}+$ screen from a gray screen $(\mathrm{S}-)$, which had no platform below it. The first trial of pretraining involved placing mice onto the hidden platform for $1 \mathrm{~min}$, and on subsequent trials, mice were released at increasing distances from the platform so that by the last two trials, they were released from the release chute.

Visual detection testing (eight trials/day for $8 \mathrm{~d}$ ) involved training the mice to swim from the release chute to the hidden platform located below a computer screen displaying a vertical grating of $0.17 \mathrm{c} / \mathrm{deg}(\mathrm{S}+)$ versus a gray screen $(\mathrm{S}-)$ that was displayed on the other computer. The $\mathrm{S}+$ was alternated between the left and right side of the divider in the sequence LRLLRLRR for the first $4 \mathrm{~d}$ of testing and then reversed (RRLRLLRL) for the last $4 \mathrm{~d}$ of testing. The number of correct trials was expressed as percentage correct for that day, and criterion was set as $70 \%$ correct. Mice began pattern discrimination testing (eight trials/ day for $8 \mathrm{~d}$ ) the day after completing the visual detection task. In this task, the mice were trained to swim toward a vertical grating of $0.17 \mathrm{c} / \mathrm{deg}(\mathrm{S}+)$, indicating the location of the hidden platform, versus a horizontal grating of $0.17 \mathrm{c} / \mathrm{deg}(\mathrm{S}-)$. All other aspects of pattern discrimination testing followed the procedure of visual detection testing. Visual acuity testing began the day after pattern discrimination testing was completed. Mice were trained (eight trials/day for $8 \mathrm{~d}$ ) to swim to a vertical grating of increasing spatial frequencies $\left(S_{+}\right)$versus a gray screen $(S-)$. The order of spatial frequencies that were displayed on the $\mathrm{S}+$ computer over the eight trials each day was $0.17,0.32,0.43,0.53,0.64,0.55$, 0.62 , and $0.57 \mathrm{c} / \mathrm{deg}$. A visual acuity threshold was obtained when a mouse failed to achieve $70 \%$ correct for a particular spatial frequency over the $8 \mathrm{~d}$ of testing.

Strain differences in percentage correct on day 8 of the visual detection and pattern discrimination tasks and in visual acuity threshold were analyzed with one-way ANOVAs and post hoc Fisher's PLSD tests (Statview 5.0, Abacus Concepts, Inc.). Strain means for percentage correct on day 8 on the visual detection and pattern discrimination tasks and the visual acuity threshold were used as measures of visual ability for correlation analyses in this article.

\section{The Morris water maze}

The water maze (Morris 1984) was a circular polypropylene pool $(110 \mathrm{~cm}$ in diameter and $20 \mathrm{~cm}$ high) filled to a depth of $14 \mathrm{~cm}$ with room-temperature tap water $\left(22^{\circ} \mathrm{C}\right)$. Five hundred milliliters of nontoxic white liquid tempera paint (Schola) was added to the water, making it opaque and ensuring camouflage of the white escape platform. For hidden platform trials, the escape platform consisted of a Plexiglas cylinder $(13.50 \mathrm{~cm}$ high, $9 \mathrm{~cm}$ in diameter), and the water level was $0.5 \mathrm{~cm}$ above the platform, making it invisible. For visible platform trials, a red top and colorful flag were added to the platform. The water maze was located in a room $(5.2 \times 2.4 \mathrm{~m})$ with posters and furniture around the walls, serving as extramaze visual cues. The performance of mice was scored using a video camera-based computer tracking system (Watermaze, Actimetrics Inc.) on an IBM PC computer, with the camera fixed to the ceiling $2.1 \mathrm{~m}$ above the pool. During testing, the room was dimly lit with diffuse white light (30 lux). Mice were tested in batches of four, and the intertrial interval was approximately $5 \mathrm{~min}$.

Mice were tested in the Morris water maze in four phases: acquisition, reversal, probe trial, and visible platform trials (Wong and Brown 2006a). In the acquisition phase (four trials/ day for $3 \mathrm{~d}$ ), mice were trained to swim to the hidden platform located in the northeast quadrant. Each mouse was removed from its holding cage using a plastic container and released from a randomly assigned start location (east, north, south, or west). If the mouse failed to find the platform within $60 \mathrm{sec}$, it was guided to the platform using a plastic container and allowed to stay on it for $\sim 10 \mathrm{sec}$. During reversal training (four trials/day for $3 \mathrm{~d}$ ), the platform was moved to the opposite quadrant (southwest), and all other aspects of reversal training followed the procedure for acquisition training. On day 7, mice were tested for spatial memory in a 60 -sec probe trial with no platform present, and on day 8 mice were tested (four trials) using a visible platform that was placed in the northwest quadrant.

Strain differences in latency to find the hidden platform and total swim distance on acquisition and reversal days were analyzed using a $13 \times 6$ (strain by days) between-within ANOVA (Statview 5.0, Abacus Concepts, Inc.). The percentage time in the correct quadrant in the probe trial was analyzed using a one-way ANOVA to investigate strain differences. One sample t-tests were used to determine whether the time spent in the correct quadrant during the probe trial was significantly different from chance $(25 \%)$. Latency to find the visible platform was analyzed as one-way ANOVAs. Post hoc analyses were conducted using Fisher's PLSD tests. Mean latency and distance to find the hidden platform during reversal training for each strain were used as measures of learning and percentage time in the correct quadrant and annulus crossings in the probe trial were used as a measure of memory for correlation analyses.

\section{Conditioned odor preference}

The conditioned odor preference task (Schellinck et al. 2001) was conducted in two phases: training and testing. Before training, mice were food deprived to $85 \%-90 \%$ of their ad libitum weight for $4 \mathrm{~d}$ and were assigned to either the $\mathrm{R}+/ \mathrm{L}$ - group (where they would receive rose $(\mathrm{R})$ odor paired with sugar and lemon $(\mathrm{L})$ odor with no sugar) or the $\mathrm{L}+/ \mathrm{R}$ - group (indicating that they would receive lemon paired with sugar and rose with no sugar). Rose (phenyl acetate) and lemon (Linalool) odors (Aldrich chemicals) were diluted to a concentration of $15 \%$ in propylene glycol, and $0.05 \mathrm{~mL}$ of the odor was placed on filter paper $(55 \mathrm{~mm}$ in diameter) in the bottom of an odor pot. The bottoms of the odor pots were made from plastic beverage cup bottoms cut to $\sim 1.5 \mathrm{~cm}$ height, and the tops were constructed from plastic Petri dishes with small holes drilled through them to allow the odor to escape.

Mice were trained in clear, plastic cages $(18.75 \times 28 \times 12.5$ $\mathrm{cm})$ with stainless steel tops. The odor pots were centered in the back two-thirds of the cage and covered by Pro chip bedding, and when the odor was paired with sugar, several grains of sugar were mixed with the Pro chip bedding. Training consisted of four 10min trials per day (two S+ trials and two $\mathrm{S}$ - trials) for $4 \mathrm{~d}$ with 10-min intertrial intervals. The order in which the odors were presented was randomized across days. Each odor was presented in a separate room that contained only the odor pots and cages used for that particular odor. After each trial, the mice were placed for $10 \mathrm{~min}$ in a room that had no odors while the filter paper and the bedding were changed.

After $4 \mathrm{~d}$ of training, mice were given an odor discrimination preference test that was conducted in $69 \times 20 \times 20$-cm box constructed from 3-mm clear acrylic. The box was divided into three equal compartments by two acrylic walls, each of which had a $6 \times 5.5-\mathrm{cm}$ opening that was closed by acrylic doors that were used to contain the mouse in the center compartment until testing started. Approximately $1000 \mathrm{~mL}$ of Pro Chip bedding was distributed over the floor of the apparatus. The preference test had two phases: habituation and testing.

Mice were habituated to the test apparatus for 2 min with odorless odor pots centered in each end compartment and covered by Pro chip bedding. The mouse was placed in the center compartment, the doors leading to the end compartments were opened, and the mouse was allowed to explore the apparatus. The time spent in each end compartment was recorded to determine position bias. After habituation, the mouse was returned to its home cage while the apparatus was made ready for testing. The test phase consisted of removing the odorless odor pots used in habituation and replacing them with odor pots containing lemon and rose odors without sugar reward. The position of the test box was rotated, left to right to control for side preference. The mouse was removed from its home cage and placed in the center compartment, and the doors leading to the end compart- 
ments were lifted. The test phase consisted of one 3-min trial, during which the time spent digging in each odor pot was recorded with stopwatches.

Strain differences in the percentage of time spent digging in the CS+ in the test phase were analyzed using one-way ANOVAs and Fisher's PLSD post hoc tests (Statview 5.0, Abacus Concepts, Inc.). Strain means for the percentage of time spent digging in the CS+ were used as a single measure of memory for correlation analyses.

\section{Motor learning in the Rotarod}

The Rotarod (AccuRotor, Accuscan Instruments Inc.) consisted of an acrylic rotating rod ( $3 \mathrm{~cm}$ thick) that was covered with a rubber mat. The rod was divided into four $11-\mathrm{cm}$ sections by white Plexiglas circular dividers (15 $\mathrm{cm}$ high). Four individual holding chambers were located $39 \mathrm{~cm}$ below the rod, and four automatic timers were built into the apparatus that started when the rod was set into motion and turned off automatically when the mouse fell into the holding chamber below the rod. The Rotarod was located in a laboratory room $(112 \times 260 \mathrm{~cm})$, which was illuminated with a single $60-\mathrm{W}$ red light bulb. Mice were tested in squads of four for $7 \mathrm{~d}$ with six trials/day with an intertrial interval of $\sim 1 \mathrm{~min}$.

Mice were placed on the rotating rod facing the opposite direction to the motion of the rod, which was set to accelerate from 0.0 to $48.0 \mathrm{rpm}$ over a 6 -min trial. The automatic timers scored the latency for the mice to fall off the rod into the chamber below, and mice remained in this chamber until all mice had fallen. If a mouse jumped from the rod, the trial was stopped and the mouse was returned to its home cage for a 1-min rest period and then it was required to redo the trial. After all four mice had fallen or the trial was completed (maximum trial duration of 6 $\mathrm{min}$ ), the motor was turned off and the mice were removed from the chamber and returned to their home cages for a 1-min rest period before beginning the next trial.

Strain differences in latency to fall on day 7 were analyzed using one-way ANOVAs. (Statview 5.0, Abacus Concepts, Inc.). Post hoc comparisons were investigated using Fisher's PLSD post hoc tests. Strain means for latency to fall on day 7 were used as a single measure of motor ability in correlation analyses. Because body weight may influence Rotarod performance (Brown et al. 2002), we also performed ANCOVAs with body weight as the covariate.

Pearson product moment correlations (Statview 5.0, Abacus Concepts, Inc.) were used to analyze the relationship between visual ability and performance in the Morris water maze, conditioned odor preference task, and the Rotarod.

\section{Results}

Because SPRET/EiJ mice were too difficult to maintain on food deprivation, they were not tested in the conditioned odor preference task, and CAST/EiJ and SPRET/EiJ mice were not tested in the Rotarod because they jumped off the rod. Sex differences are discussed only when significant. When sex differences were not significant, data for males and females were pooled for further analyses.

\section{Body weight}

Figure 1 shows the mean $( \pm$ SEM) body weight of males and females of each strain on day 7 of Rotarod testing. There were significant strain differences in body weight $\left(F_{(10,254)}=91.92\right.$, $P<0.001)$, significant sex differences $\left(F_{(1,254)}=296.38\right.$, $P<0.001)$, and a significant strain by sex interaction $\left(F_{(10,254)}=4.30, P<0.001\right)$. Post hoc t-tests showed that males were significantly heavier than females in all strains $(P<0.01)$ except for MOLF/EiJ, in which males and females did not differ in weight $(P=0.08)$.

Because of the sex differences, strain differences in body weight were analyzed separately for each sex. There were significant strain differences in body weight in males $\left(F_{(10,129)}=44.52\right.$,

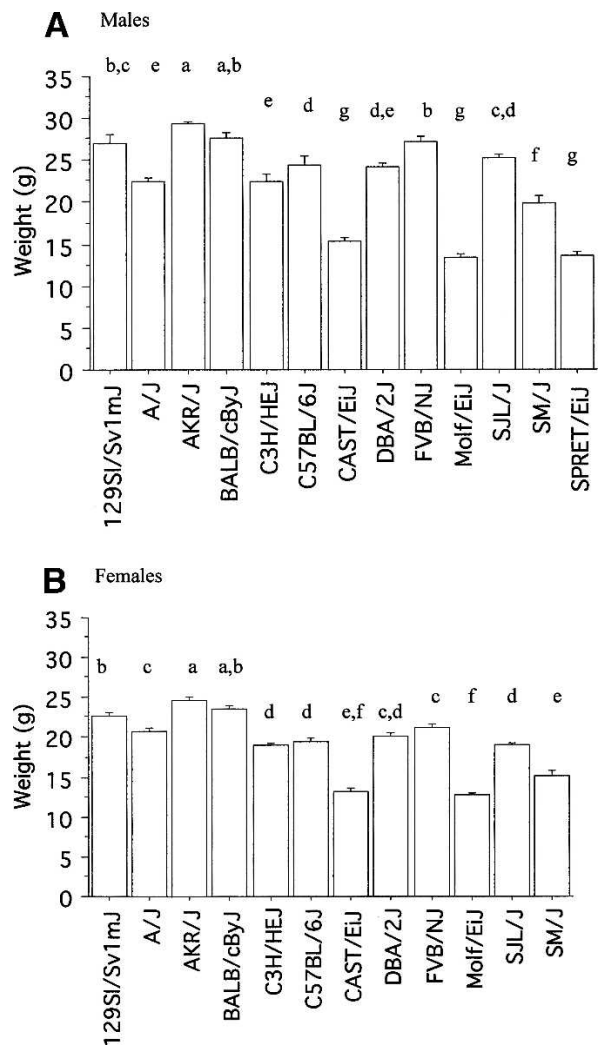

Figure 1. Mean ( \pm SEM) body weights $(g)$ for male $(A)$ and female $(B)$ mice of each strain tested. Strains with different letters have significant differences in body weights $(P<0.05)$.

$P<0.001$ ), with $\mathrm{AKR} / \mathrm{J}$ and BALB/cByJ being the heaviest and CAST/EiJ, MOLF/EiJ and SPRET/EiJ being the lightest (Fig. 1A). Likewise there was a significant difference between strains in the weights of female mice, with $\mathrm{AKR} / \mathrm{J}$ and BALB/cByJ being the heaviest and CAST/EiJ and MOLF/EiJ being the lightest (Fig. 1B).

\section{Vision task}

We have previously reported consistent strain differences and no sex differences in visual detection, pattern discrimination, and visual acuity threshold in 14 strains of mice (Wong and Brown 2006b). These strain differences were predicted by the physiology of the visual system as mice with reported normal vision (129S1/ SvImJ, C57BL/6J, and DBA/2J) and one albino strain (AKR/J) performed very well in these tasks. The other albino strains $(\mathrm{A} / \mathrm{J}$, $\mathrm{BALB} / \mathrm{CByJ}$, and BALB/cJ) took longer to learn the tasks than did mice with normal vision and did not reach the criterion of $70 \%$ correct. Mice with retinal degeneration $(\mathrm{C} 3 \mathrm{H} / \mathrm{HeJ}, \mathrm{FVB} / \mathrm{NJ}$, $\mathrm{MOLF} / \mathrm{EiJ}$, and SJL/J) performed only at chance levels, as did the three strains with unknown visual abilities (CAST/EiJ, SM/J, and SPRET/EiJ). In the present article, we used day 8 performance in the visual detection and pattern discrimination tasks and visual acuity threshold from Wong and Brown (2006b) as measures of visual ability. Wong and Brown (2006b) provide a complete analysis of strain differences in ability to reach criterion, strain by day analyses of correct responses, latency to reach the platform, and swim path analysis in the vision task.

There were significant strain differences in percentage correct on day 8 of the visual detection task $\left(F_{(12,157)}=9.68\right.$, $P<0.001)$ as the three strains of mice with reported normal vision (129S1/SvImJ, C57BL/6J, and DBA/2J) and two albino strains (AKR/J and BALB/cByJ) outperformed all other strains tested. In 
the pattern discrimination task, strains also differed significantly $\left(F_{(12,157)}=10.13, P<0.001\right)$, with AKR/J and DBA/2J mice performing significantly better than all other strains tested (Table 2). Only five strains (129S1/SvImJ, AKR/J, BALB/cByJ, C57BL/6J, and DBA/2J) had a defined visual acuity threshold. No other strains were able to reach criterion (70\% correct) at any spatial frequency tested; thus, their visual acuity threshold was set at $0 \mathrm{c} / \mathrm{deg}$ (Table 2).

\section{Morris water maze}

\section{Latency to reach the hidden platform}

A $13 \times 6$ (strain by days) between/within ANOVA indicated that there were significant strain differences in latency to reach the hidden platform $\left(F_{(12,220)}=22.97, P<0.0001\right)$, a significant decrease in latency over the six days of training $\left(F_{(5,1100)}=60.97\right.$, $P<0.0001)$, and a significant strain by day interaction $\left(F_{(60,1100)}=3.09, P<0.0001\right)$. Post hoc analyses revealed that C57BL/6J and DBA/2J mice located the platform faster than the other 11 strains tested, followed by 129S1/SvImJ, AKR/J, and $\mathrm{SM} / \mathrm{J}$ mice (Fig. 2). Table 2 shows the mean latency to find the platform averaged over the $3 \mathrm{~d}$ of reversal training (days 4-6) for each strain of mice tested.

\section{Swim distance to reach the hidden platform}

A $13 \times 6$ (strain by days) between/within ANOVA revealed that strains differed significantly in their swim distance $\left(F_{(5,240)}=35.03, P<0.0001\right)$ as $129 \mathrm{~S} 1 /$ SvImJ, C57BL/6J, AKR/J, and $\mathrm{SM} / \mathrm{J}$ mice swam the shortest distance to find the hidden platform (Fig. 3). There was a significant decrease in swim distance over days tested $\left(F_{(5,240)}=35.03, P<0.0001\right)$, and the strain by day interaction was also significant $\left(F_{(5,240)}=35.03\right.$, $P<0.0001)$. Table 2 shows the mean swim distance for each strain to find the platform averaged over the three days of reversal training.

\section{Swim speed}

There were significant strain differences in swim speed $\left(F_{(12,223)}=22.37, P<0.0001\right)$, as $\mathrm{FVB} / \mathrm{NJ}$ and DBA/2J mice had the fastest swim speed (Table 2) while 129/SvImJ mice had the slowest swim speed.

Percentage time spent in the correct quadrant during the probe trial There were significant strain differences in the percentage of time spent in the correct quadrant during the probe trial $\left(F_{(12,220)}=4.63, P<0.0001\right)$, as FVB/NJ, C57BL/6J, 129S1/SvImJ, and DBA/2J mice spent the greatest amount of time in the correct quadrant (Table 2). $t$-Tests showed that FVB/NJ $\left(t_{(11)}=4.21\right.$, $P<0.01)$, C57BL/6J $\left(t_{(18)}=6.04, P<0.0001\right), 129 \mathrm{~S} 1 / \mathrm{SvImJ}$ $\left(t_{(13)}=3.15, P<0.0001\right), \mathrm{DBA} / 2 \mathrm{~J}\left(t_{(11)}=3.65, P<0.01\right)$, and SM/J mice $\left(t_{(19)}=2.82, P<0.05\right)$ were the only strains that spent more time in the correct quadrant than predicted by chance.

\section{Annulus crossings}

There were significant strain differences in annulus crossings in the probe trial $\left(F_{(12,220)}=7.25, P<0.0001\right)$ as $\mathrm{C} 57 \mathrm{BL} / 6 \mathrm{~J}$ mice had the greatest number of annulus crossings and $\mathrm{A} / \mathrm{J}$ and BALB/cByJ mice had the least (Table 2).

\section{Visible platform test}

Strains differed significantly in their latency to reach the visible platform $\left(F_{(12,220)}=20.21, P<0.0001\right)$. Post hoc analysis revealed that $\mathrm{C} 57 \mathrm{BL} / 6 \mathrm{~J}, \mathrm{DBA} / 2 \mathrm{~J}, \mathrm{AKR} / \mathrm{J}$, and $\mathrm{SM} / \mathrm{J}$ mice found the visible platform significantly faster than any of the other strains tested and MOLF/EiJ and SPRET/EiJ mice were the slowest (Table 2).

\section{Conditioned odor preference}

Although AKR/J mice spent the least time digging in the CS+ on the test day, there were no significant strain differences in the percentage of digging in the $\mathrm{CS}+$ in the preference test $\left(F_{(11,233)}=1.39, P=\mathrm{NS}\right)$ (Table 2 ; Fig. 4$)$, and all strains spent $>70 \%$ of their time digging in the CS+.

\section{Rotarod}

Because there were significant sex differences $\left(F_{(1,259)}=28.57\right.$, $P<0.0001)$ in the latency to fall on day 7 of the Rotarod, with females taking significantly longer to fall than males, these data were analyzed separately for males and females.
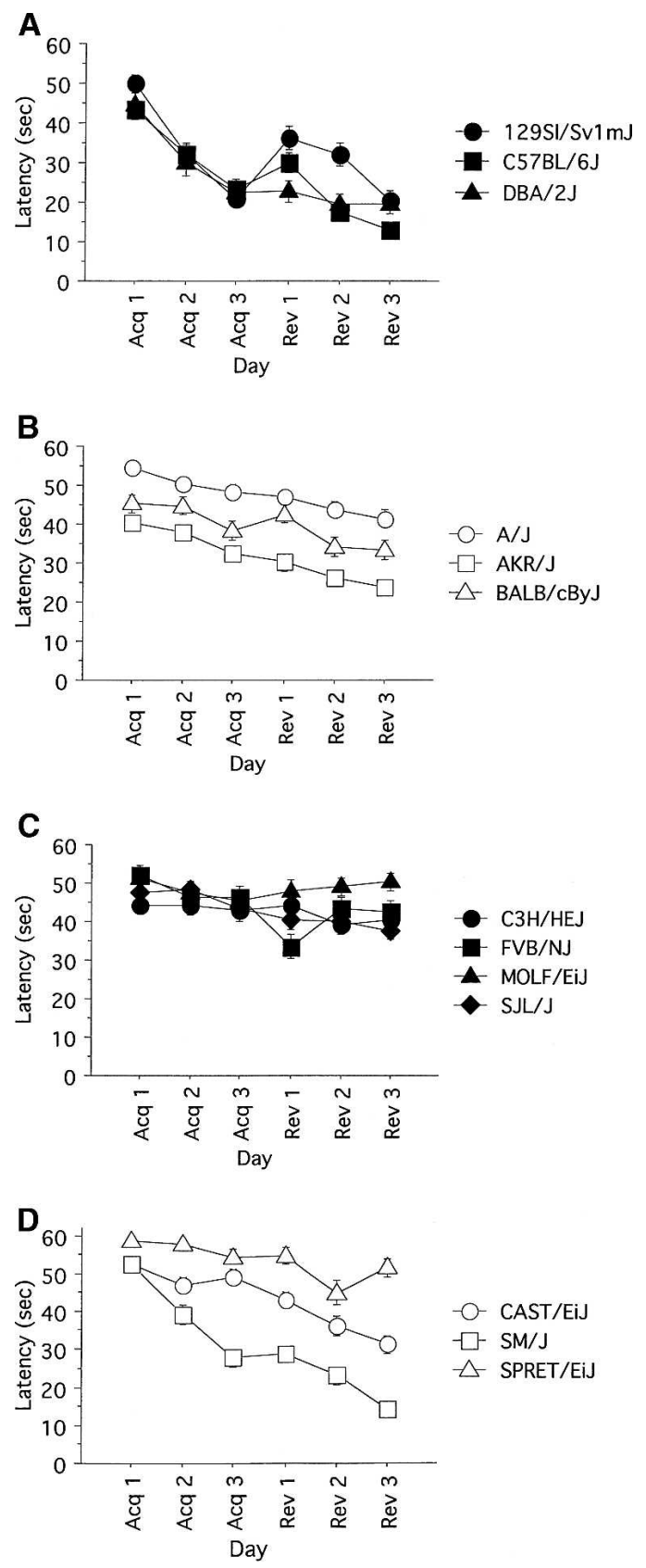

Figure 2. Mean latency (sec) to reach the hidden platform in the Morris water maze on each day of acquisition and reversal training for strains of mice with normal vision $(A)$, albinism (B), retinal degeneration $(C)$, and unknown visual abilities $(D)$.

\section{Learning \& Memory}




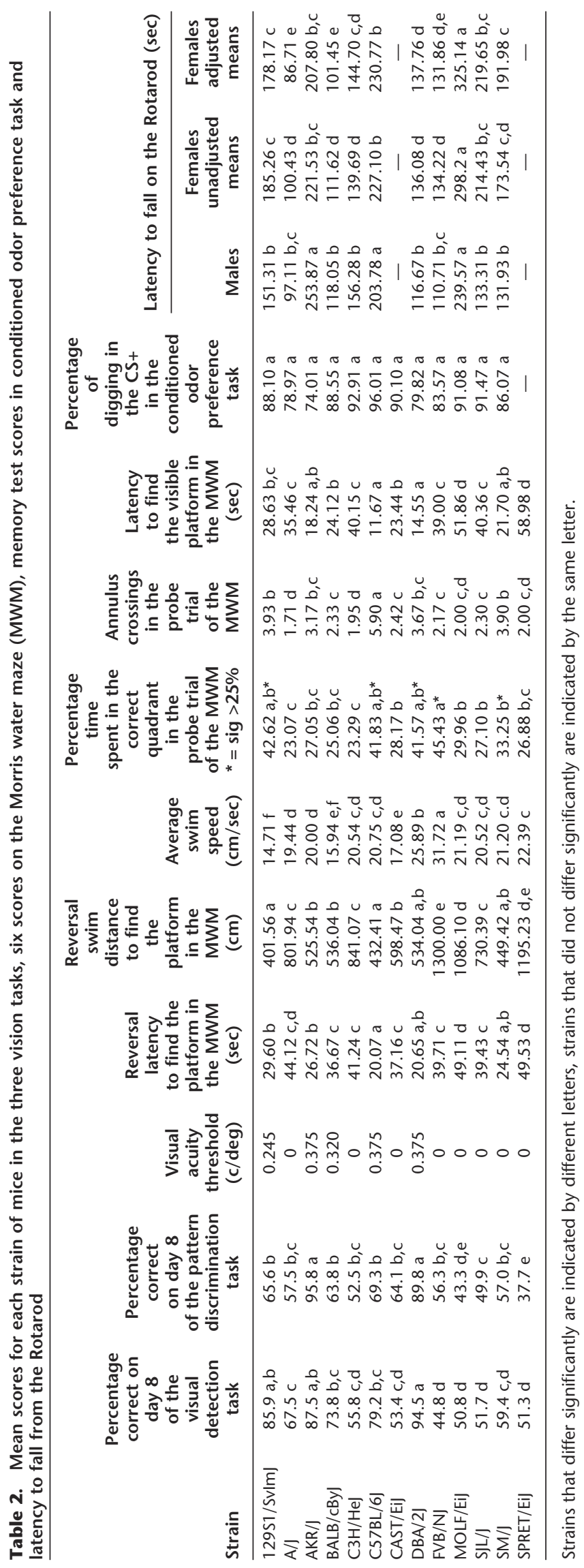



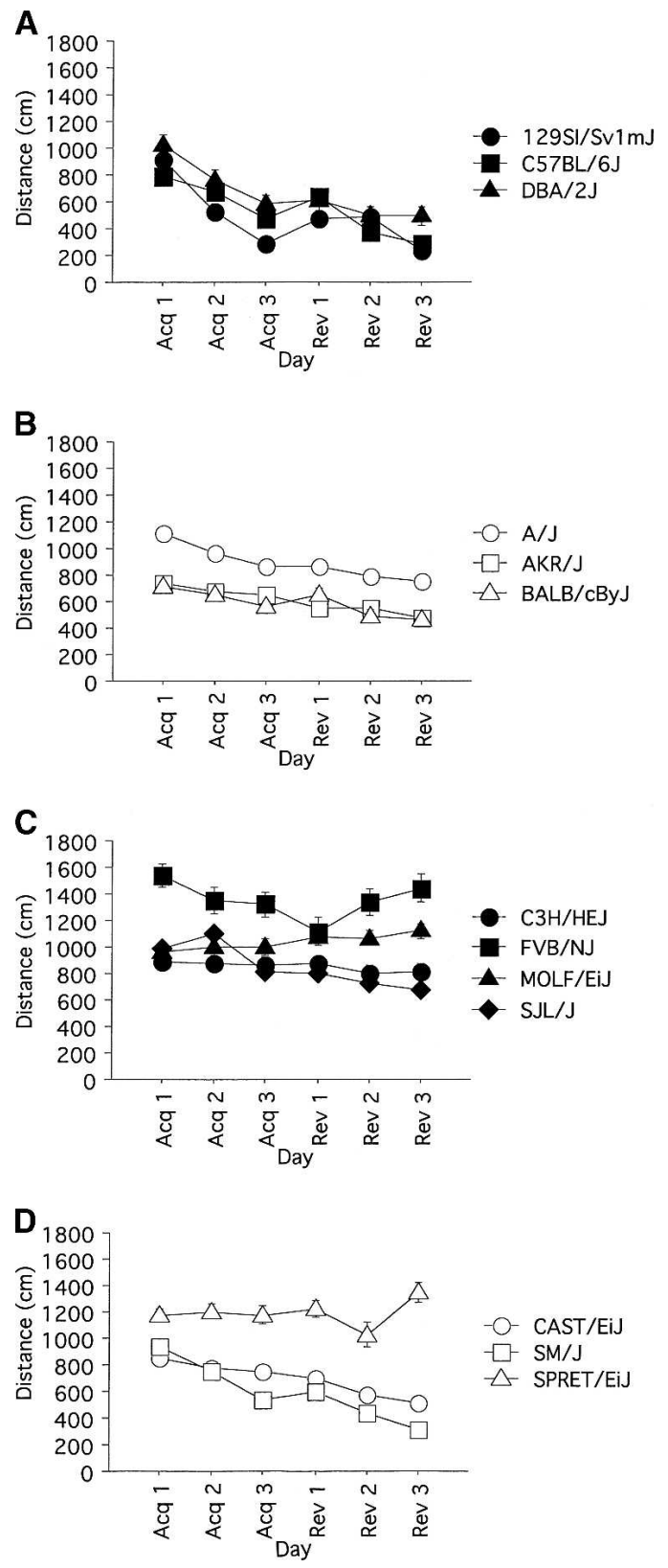

Figure 3. Mean swim distance $(\mathrm{cm})$ to reach the hidden platform in the Morris water maze on each day of acquisition and reversal training for strains of mice with normal vision $(A)$, albinism $(B)$, retinal degeneration $(C)$, and unknown visual abilities $(D)$.

\section{Males}

There were significant strain differences in latency to fall in male mice $\left(F_{(10,129)}=16.02, P<0.0001\right)$, as AKR/J and MOLF/EiJ mice stayed on the Rotarod the longest and $\mathrm{FVB} / \mathrm{NJ}$ and $\mathrm{A} / \mathrm{J}$ stayed on the shortest (Table 2). The correlation between body weight and latency to fall on the Rotarod, however, was not significant in male mice $(r=-0.12, n=140$, NS).

\section{Females}

Significant strain differences within female mice $\left(F_{(10,125)}=\right.$ 19.54, $P<0.0001$ ) indicated that MOLF/EiJ mice took significantly longer to fall than any other strain tested and $\mathrm{A} / \mathrm{J}$ and BALB/cByJ fell off first (Table 2). The correlation between body weight and latency to fall on the Rotarod was significant in female mice $(r=-0.34, n=136, P<0.01)$; therefore, latency to fall on day 7 was analyzed using an ANCOVA with body weight as the covariate. Using strain means adjusted for body weight, there were still significant strain differences in latency to fall $\left(F_{(10,124)}=14.36, P<0.0001\right)$ (Table 2$)$.

\section{Correlations between visual ability and measures of learning and memory}

\section{Morris water maze}

There were significant negative correlations between visual ability and measures of learning in the hidden platform version of the Morris water maze, indicating that mice that performed poorly in the visual detection task took longer and swam a greater distance to find the hidden platform than did mice with good visual detection ability. Although visual ability was not significantly correlated with percentage time spent in the correct quadrant of the Morris water maze during the probe trial, visual detection performance and visual acuity threshold were positively correlated with the number of annulus crossings in the probe trial. All three measures of visual ability were negatively correlated with latency to find the visible platform, indicating that mice with better vision found the visible platform faster than did mice with poor vision (Fig. 5; Table 3).

\section{Conditioned odor preference task}

There was a significant negative correlation between visual ability in the pattern discrimination task and the percentage of digging in the CS+ in the conditioned odor preference task, indicating that mice that had poorer vision had better olfactory memory (Table 3).

\section{Motor learning in the Rotarod}

There were no significant correlations between performance on the vision tasks and latency to fall on day 7 of the Rotarod for males or females (Table 3).

\section{Discussion}

The results reported here demonstrate that mice that performed poorly in the vision tasks took longer and swam a greater distance to find the hidden platform in learning the Morris water maze. These visual deficits did not impair performance in a motorlearning task or a conditioned odor preference task. Thus, these results indicate that strain differences in visual ability are a confounding factor in tests of visuo-spatial learning and indicate that visual ability accounts for a high proportion of between-strain variance in mice in acquisition and memory in the Morris water maze. For example, measures of visual ability accounted for 53\%-61\% of the between-strain variance in latency and $40 \%-53 \%$ of the be-

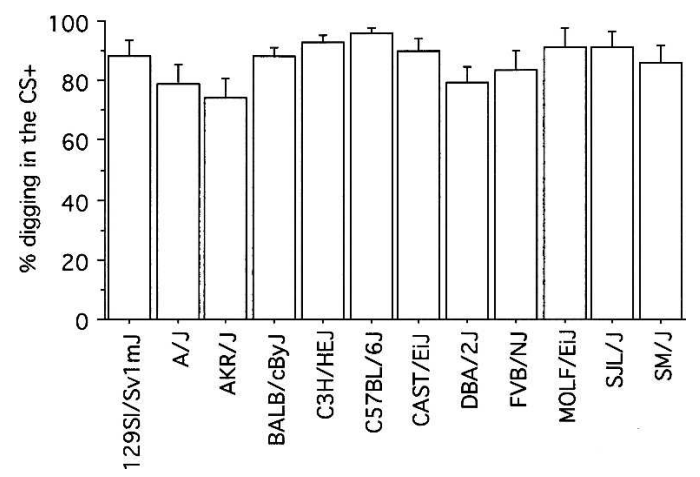

Figure 4. Mean ( \pm SEM) percentage of digging in the CS+ in the conditioned odor preference test for each strain tested. 

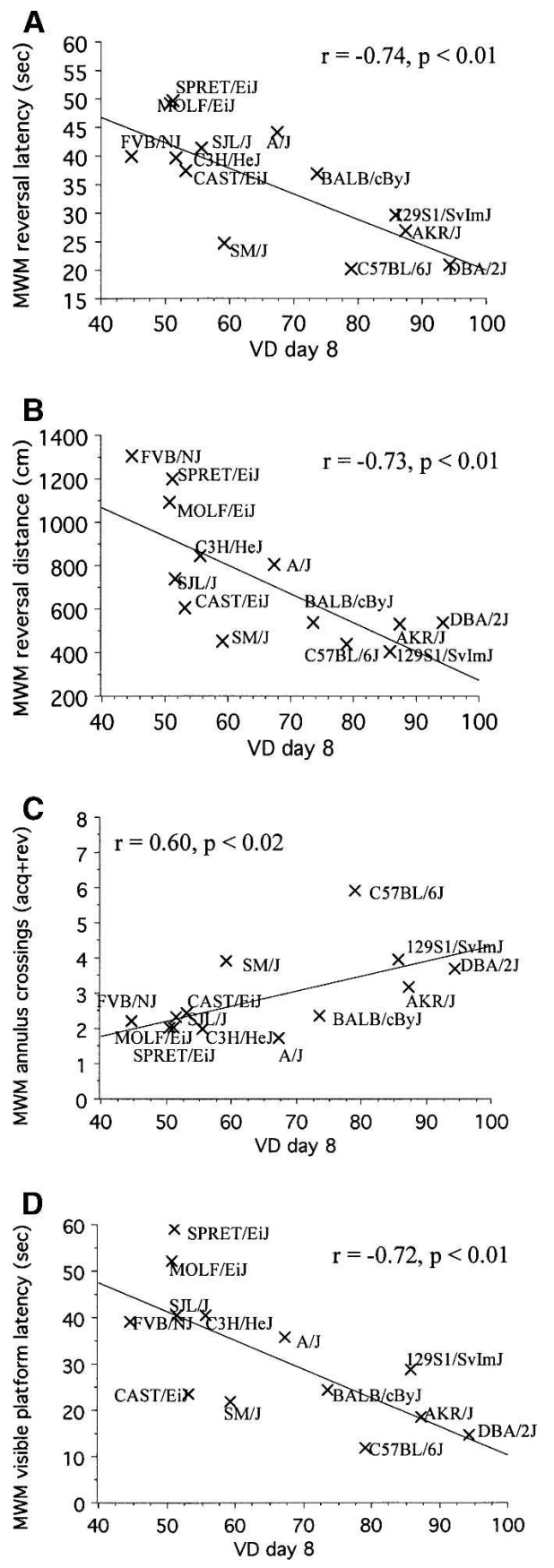

Figure 5. Regression plots showing the correlation of strain means between percentage correct on day 8 of the visual detection task (VD 8) and mean reversal latency $(\mathrm{sec}, A)$, mean reversal swim distance $(\mathrm{cm}, B)$, number of annulus crossings ( $C$ ), and mean visible platform latency (sec, $D$ ) in the Morris water maze. Visual ability was significantly correlated with all four measures of performance in the water maze (see Table 3).

tween-strain variance in swim distance in learning the hidden platform version of the water maze and $52 \%-69 \%$ of the between-strain variance in learning the visible platform location.

The poor performance exhibited by mice with poor visual ability in the Morris water maze was not due to a general impairment in learning and memory because all strains were able to learn a conditioned odor preference and a motor learning task. In fact, the significant correlation between the percentage of time spent digging in the CS+ in the odor preference task and percent- age correct on day 8 of the pattern discrimination task indicates that olfactory memory was enhanced in mouse strains with poor visual abilities.

We have found similar results in the aging DBA/2J mouse, which is a model of pigmentary glaucoma (Anderson et al. 2002; Moon et al. 2005; Zhou et al. 2005). At 6 mo of age, DBA/2J mice outperformed C57BL/6J mice in the visual detection task, and there were no strain differences in performance on the Morris water maze. However, at 12, 18, and 24 mo of age, C57BL/6J mice outperformed DBA/2J mice in the vision tasks and in the water maze (Wong and Brown 2006a). These behavioral results correlate well with the morphological and functional changes in the visual system of aging DBA/2J mice, in which retinal ganglion cell loss occurs between 8 and 12 mo of age (Bayer et al. 2001; Danias et al. 2003; Moon et al. 2005). As in the present study, there was a significant correlation between visual ability and each measure of learning and memory in the Morris water maze at 12 and 18 mo of age in DBA/2J and C57BL/6J mice, with visual ability accounting for up to $60 \%$ of the variability in learning and $46 \%$ of the variability in memory in the Morris water maze. There was no effect of visual ability on learning the olfactory discrimination task, but mice with poor vision had a better olfactory memory than did mice with good vision at 18 mo of age, indicating that olfactory memory improved as mice went blind (Wong and Brown 2006a).

Because cognitive processes such as spatial learning or working memory cannot be measured directly but are inferred from task performance (Roullet and Lassalle 1995), poor performance in visuo-spatial learning and memory tasks can indicate a defect in noncognitive factors such as swim pattern or visual ability, rather than an impairment in learning or memory ability. For example, when Wolfer et al. (1998) reanalyzed the swim paths of $\sim 1400$ mice in the Morris water maze, $>68 \%$ of the observed variability in behavior scores could be accounted for by thigmotaxis and passivity, while only $13 \%$ of behavioral variability was accounted for by memory. Long-Evans rats deprived of pattern vision during a critical period of development performed significantly worse than did control rats in the hidden platform version of the Morris water maze but did not differ from nondeprived rats in their ability to locate a visible platform (Prusky et al. 2000b). Likewise, mice with poor vision (CBA, C3H/HE, and BALB/c) exhibited poor performance in a modified radial arm maze in which the experimental procedure restricted the use of visual cues to distal locations, while mice with normal vision (C57BL/6 and $\mathrm{DBA} / 2$ ) were able to learn the task (Roullet and Lassalle 1995). When $\mathrm{C} 3 \mathrm{H} / \mathrm{HeJ}$ and $\mathrm{CBA} / \mathrm{J}$ mice, both of which possess the $r d 1$ mutation of the $P d e 6 b$ gene causing retinal degeneration, were compared in the Morris water maze with two Pde6b wildtype strains (C3A.BLiA-Pde6b $b^{+} \mathrm{J}$ and CBA/CaJ) that do not have retinal degeneration, only the wild-type strains were able to demonstrate spatial learning (Clapcote et al. 2005a).

The results from the current study are important in the context of behavioral genetics because the search for genes underlying learning and memory may be confounded by visual disability. Few tests are used to investigate visual ability in mice (Pinto and Enroth-Cugell 2000; Prusky et al. 2000a); however, many widely used behavioral tests of learning and memory, such as the Morris water maze, Barnes maze, and the eight-arm radial maze, are visuo-spatial tests of cognitive function. Animals with impaired visual acuity may perform poorly on these tasks, not because of cognitive impairment but because of poor vision. This distinction is extremely important in the study of animal models of human neural disorders. Many transgenic mouse models of human neurological diseases (e.g., Alzheimer's disease, Down syndrome, and traumatic brain injury) use background strains of mice such as $\mathrm{FVB} / \mathrm{NJ}$ or $\mathrm{C} 3 \mathrm{H} / \mathrm{HeJ}$ that have retinal degeneration 
Table 3. Correlations between visual ability and performance in the Morris water maze (MWM), conditioned odor preference task, and Rotarod

\begin{tabular}{|c|c|c|c|c|c|c|c|c|c|}
\hline & \multirow[b]{2}{*}{$\begin{array}{l}\text { Mean } \\
\text { reversal } \\
\text { latency in } \\
\text { the MWM } \\
(\mathrm{sec})\end{array}$} & \multirow{2}{*}{$\begin{array}{c}\text { Mean } \\
\text { reversal } \\
\text { swim } \\
\text { distance } \\
\text { in the MWM } \\
(\mathrm{cm})\end{array}$} & \multirow{2}{*}{$\begin{array}{l}\text { Percentage } \\
\text { time } \\
\text { spent in the } \\
\text { correct } \\
\text { quadrant } \\
\text { in the probe } \\
\text { trial of the } \\
\text { MWM }\end{array}$} & \multirow{2}{*}{$\begin{array}{l}\text { Annulus } \\
\text { crossings } \\
\text { during the } \\
\text { probe trial } \\
\text { of the } \\
\text { MWM }\end{array}$} & \multirow{2}{*}{$\begin{array}{l}\text { Mean } \\
\text { latency } \\
\text { to find the } \\
\text { visible } \\
\text { platform } \\
\text { in the } \\
\text { MWM } \\
\text { (sec) }\end{array}$} & \multirow{2}{*}{$\begin{array}{l}\text { Percentage } \\
\text { of digging } \\
\text { in the CS+ } \\
\text { in the } \\
\text { conditioned } \\
\text { odor } \\
\text { preference } \\
\text { task }\end{array}$} & \multicolumn{3}{|c|}{$\begin{array}{c}\text { Latency to fall on day } 7 \\
\text { of the Rotarod (sec) }\end{array}$} \\
\hline & & & & & & & Males & Fem & $\begin{array}{c}\text { Females } \\
\text { adjusted } \\
\text { for body } \\
\text { weight }\end{array}$ \\
\hline $\begin{array}{l}\text { \% Correct in the visual } \\
\text { detection task } \\
\text { on day } 8\end{array}$ & $\begin{aligned} r & =-0.74 \\
n & =13 \\
P & <0.01 \\
r^{2} & =0.54\end{aligned}$ & $\begin{aligned} r & =-0.73 \\
n & =13 \\
P & <0.01 \\
r^{2} & =0.53\end{aligned}$ & $\begin{aligned} r & =0.29 \\
n & =13 \\
P & =\mathrm{NS} \\
r^{2} & =\mathrm{NS}\end{aligned}$ & $\begin{aligned} r & =0.60 \\
n & =13 \\
P & <0.02 \\
r^{2} & =0.36\end{aligned}$ & $\begin{aligned} r & =-0.72 \\
n & =13 \\
P & <0.01 \\
r^{2} & =0.52\end{aligned}$ & $\begin{aligned} r & =-0.41 \\
n & =12 \\
P & =\mathrm{NS} \\
r^{2} & =\mathrm{NS}\end{aligned}$ & $\begin{aligned} r & =0.15 \\
n & =11 \\
P & =\mathrm{NS} \\
r^{2} & =\mathrm{NS}\end{aligned}$ & $\begin{aligned} r & =-0.11 \\
n & =11 \\
P & =\mathrm{NS} \\
r^{2} & =\mathrm{NS}\end{aligned}$ & $\begin{aligned} r & =-0.17 \\
n & =11 \\
P & =\mathrm{NS} \\
r^{2} & =\mathrm{NS}\end{aligned}$ \\
\hline $\begin{array}{l}\% \text { Correct in the } \\
\text { pattern discrimination } \\
\text { task on day } 8\end{array}$ & $\begin{aligned} r & =-0.78 \\
n & =13 \\
P & <0.01 \\
r^{2} & =0.61\end{aligned}$ & $\begin{aligned} r & =-0.63 \\
n & =13 \\
P & <0.01 \\
r^{2} & =0.40\end{aligned}$ & $\begin{aligned} r & =0.28 \\
n & =13 \\
P & =\mathrm{NS} \\
r^{2} & =\mathrm{NS}\end{aligned}$ & $\begin{aligned} r & =0.48 \\
n & =13 \\
P & =\mathrm{NS} \\
r^{2} & =\mathrm{NS}\end{aligned}$ & $\begin{aligned} r & =-0.83 \\
n & =13 \\
P & <0.01 \\
r^{2} & =0.69\end{aligned}$ & $\begin{aligned} r & =-0.62 \\
n & =12 \\
P & <0.05 \\
r^{2} & =0.38\end{aligned}$ & $\begin{aligned} r & =0.21 \\
n & =11 \\
P & =\mathrm{NS} \\
r^{2} & =\mathrm{NS}\end{aligned}$ & $\begin{aligned} r & =-0.12 \\
n & =11 \\
P & =\mathrm{NS} \\
r^{2} & =\mathrm{NS}\end{aligned}$ & $\begin{aligned} r & =-0.20 \\
n & =11 \\
P & =\mathrm{NS} \\
r^{2} & =\mathrm{NS}\end{aligned}$ \\
\hline $\begin{array}{l}\text { Visual acuity threshold } \\
\text { (c/deg) }\end{array}$ & $\begin{aligned} r & =-0.73 \\
n & =13 \\
P & <0.01 \\
r^{2} & =0.53\end{aligned}$ & $\begin{aligned} r & =-0.63 \\
n & =13 \\
P & <0.01 \\
r^{2} & =0.40\end{aligned}$ & $\begin{aligned} r & =0.35 \\
n & =13 \\
P & =\mathrm{NS} \\
r^{2} & =\mathrm{NS}\end{aligned}$ & $\begin{aligned} r & =0.65 \\
n & =13 \\
P & <0.02 \\
r^{2} & =0.42\end{aligned}$ & $\begin{array}{l}r=-0.83 \\
n=13 \\
P< \\
r^{2}=0.69\end{array}$ & $\begin{aligned} r & =-0.23 \\
n & =12 \\
P & =\mathrm{NS} \\
r^{2} & =\mathrm{NS}\end{aligned}$ & $\begin{aligned} r & =0.28 \\
n & =11 \\
P & =\mathrm{NS} \\
r^{2} & =\mathrm{NS}\end{aligned}$ & $\begin{aligned} r & =0.01 \\
n & =11 \\
P & =\mathrm{NS} \\
r^{2} & =\mathrm{NS}\end{aligned}$ & $\begin{aligned} r & =-0.07 \\
n & =11 \\
P & =\mathrm{NS} \\
r^{2} & =\mathrm{NS}\end{aligned}$ \\
\hline
\end{tabular}

NS, not significant.

or DBA/2J mice that suffer from age-related blindness (Fox et al. 1999; Lalonde et al. 2004; Schmitt et al. 2006).

Furthermore, many transgenic mice are maintained on a hybrid background in which one of the progenitor strains has retinal degeneration (e.g., $\mathrm{FVB} / \mathrm{N} \times \mathrm{C} 57 \mathrm{BL}, \mathrm{C} 3 \mathrm{H} \times \mathrm{C} 57 \mathrm{BL}$, Black Swiss $\times 129 / \mathrm{Sv}$ ), resulting in $25 \%$ of the offspring being homozygous for retinal degeneration. For example, Garcia et al. (2004) found that $40 \%$ of normal and Alzheimer's transgenic mice from the progeny of $\mathrm{C} 57 \mathrm{~B} 6 / \mathrm{SJL} \times \mathrm{SW} / \mathrm{B} 6 \mathrm{D} 2 \mathrm{~F}$ and $\mathrm{C} 57 \mathrm{BL} / \mathrm{DBA} 2 / \mathrm{SW}$ mice were homozygous recessive for the retinal degeneration gene, and homozygous mice showed impaired performance in the Morris water maze and radial arm water maze task. Thus, in order to evaluate the usefulness of an animal model for cognitive function, they must be tested in behavioral tests that measure learning and memory independently of such sensory deficits. Therefore, when using transgenic and mutant mice as models for human neurodegenerative disorders, it is important to carefully select the background strain so that noncognitive factors such as sensory deficits that are inherent to that strain do not affect task performance and thus, decrease the usefulness of a particular animal model. If in doubt, transgenic mice should be tested for visual ability before being used in visuo-spatial tests of learning and memory (Smith et al. 1998; Serfilippi et al. 2004; Stasko and Costa 2004).

Another area in which it is important to dissociate sensory from cognitive deficits is in the examination of strain differences in the role of LTP in learning and memory. The relationship of LTP to hippocampus-dependent learning and memory ability is of particular interest in tests of spatial learning. One way to examine this relationship is to correlate hippocampal synaptic plasticity with behavioral performance, so that deficits in learning and memory performance may be compared with altered synaptic plasticity (Schimanski and Nguyen 2004). However, if mice perform poorly in the spatial learning tasks because of poor visual ability, the association with hippocampal LTP is confounded. For example, $\mathrm{CBA} / \mathrm{J}$ mice, a strain of mice with retinal degeneration, performed poorly in the Morris water maze, and this deficit was associated with an impairment in hippocampal LTP (Nguyen et al. 2000). Although it is possible that poor Morris water maze performance is due to a deficit in LTP in CBA/J mice, this example illustrates that manipulations used to investigate the role of LTP in learning and memory engage other mechanisms, such as visual or motor ability, that are unrelated to hippocampal LTP or memory but yet influence the performance of mice on these measures. These sensory confounds weaken the evidence for a causal link between hippocampal LTP and spatial memory.

Quantitative trait loci (QTL) methods have been employed in an attempt to map genes underlying polygenic traits such as locomotor behavior (Mhyre et al. 2005), anxiety (Henderson et al. 2004), contextual fear conditioning (Radcliffe et al. 2000), and spatial learning in the Morris water maze (Owen et al. 1997; Leil et al. 2002; Steinberger et al. 2003). QTL analysis involves studying phenotypic traits in multiple strains of mice to determine the locus of the genes regulating these traits (Henderson et al. 2004; Mhyre et al. 2005). However, the tasks that are used to behaviorally phenotype mice often rely on visual cues (open field, elevated plus maze, contextual fear conditioning, Morris water maze), and deficits in visual ability can confound the search for candidate genes for locomotor, anxiety, learning, and memory. For example, anxiety-related behaviors in the elevated zero-maze are affected by retinal degeneration (Cook et al. 2001), and some measures of anxiety (center frequency in the open field) are significantly correlated with visual ability, but others (proportion of time spent in the light zone in the light/dark transition test) are not (Wong and Brown 2004). Therefore, QTL mapping strategies that aim to understand the genetic bases of complex traits must realize that the background strain is critical to the results of the experiment and therefore must be considered in the interpretation of the results (see Owen et al. 1997).

The same is true for studies aimed at unraveling the genetic, molecular, and cellular bases of learning and memory using a forward genetics approach, in which mice are first phenotyped for particular types of learning and memory deficits, and then molecular, cellular, and genetic correlates of these deficits are identified (Leil et al. 2002; Fernandes et al. 2004; Mineur et al. 2004; Schimanski and Nguyen 2004; Nadler et al. 2006). It is important to determine that the search for genetic, cellular, and molecular mechanisms underlying learning and memory is not confounded by sensory, motor, or other noncognitive differences between the mice tested.

\section{Acknowledgments}

We thank Rhian Gunn, Tim O'Leary, Nikki Hoffman, Lisa Currie, and Vicki Savoie for their assistance in testing mice and collect-

\section{Learning \& Memory}

www.learnmem.org 
ing data. Generous funds from AstraZeneca R\&D Boston were used to defray the cost of mice through the JAX Mouse Phenome Project (The Jackson Laboratory, Bar Harbour, ME). The research was supported by a grant from NSERC of Canada to R.E.B. A.A.W. was supported by a Dalhousie University Postgraduate Fellowship.

\section{References}

Abusaad, I., MacKay, D., Zhao, J., Stanford, P., Collier, D.A., and Everall, I.P. 1999. Stereological estimation of the total number of neurons in the murine hippocampus using the optical disector. J. Comp. Neurol. 408: $560-566$

Anderson, M.G., Smith, R.S., Hawes, N.L., Zabaleta, A., Chang, B., Wiggs, J.L., and John, S.W.M. 2002. Mutations in genes encoding melanosomal proteins cause pigmentary glaucoma in DBA/2J mice. Nat. Genet. 30: 81-85.

Bailey, K.R., Rustay, N.R., and Crawley, J.N. 2006. Behavioral phenotyping of transgenic and knockout mice: Practical concerns and potential pitfalls. ILAR J. 47: 124-131.

Bayer, A.U., Neuhardt, T., May, A.C., Martus, P., Maag, K., Brodie, S., Lutjen-Drecoll, E., Podos, S.M., and Mittag, T. 2001. Retinal morphology and ERG response in the DBA/2NNia mouse model of angle-closure glaucoma. Invest. Ophthalmol. Vis. Sci. 42: 1258-1265.

Bothe, G.W.M., Bolivar, V.J., Vedder, M.J., and Geistfeld, J.G. 2005. Behavioral differences among 14 inbred mouse strains commonly used as disease models. Comp. Med. 55: 326-334.

Brennan, F.X. 2004. Genetic differences in leverpress escape/avoidance conditioning in seven mouse strains. Genes Brain Behav. 3: 110-114.

Brooks, S.P., Pask, T., Jones, L., and Dunnett, S.B. 2005. Behavioral profiles of inbred mouse strains used as transgenic backgrounds. II: cognitive tests. Genes Brain Behav. 4: 307-317.

Brown, R.E., Stanford, L., Houghton, D., Williamson, M., Currie, L., Luedemann, K., and Hawken, C. 2002. Body weight as a confound in Rotarod studies of motor learning and coordination in rats and mice. Abstract no. 267.12. Society for Neuroscience, Orlando, Florida.

Carman, H.M. and Mactutus, C.F. 2002. Proximal versus distal cue utilization in spatial navigation: The role of visual acuity? Neurobiol. Learn. Mem. 78: 332-346.

Chang, B., Hawes, N.L., Hurd, R.E., Davisson, M.T., Nusinowitz, S., and Heckenlively, J.R. 2002. Retinal degeneration mutants in the mouse. Vision Res. 42: 517-525.

Clapcote, S.J., Lazar, N.L., Bechard, A.R., and Roder, J.C. 2005a. Effect of the $r d 1$ mutation and host strain on hippocampal learning in mice. Behav. Genet. 35: 591-601.

Clapcote, S.J., Lazar, N.L., Bechard, A.R., Wood, G.A., and Roder, J.C. 2005b. NIH Swiss and Black Swiss mice have retinal degeneration and performance deficits in cognitive tests. Comp. Med. 55: 310-316.

Cook, M.N., Williams, R.W., and Flaherty, L. 2001. Anxiety-related behaviors in the elevated zero-maze are affected by genetic factors and retinal degeneration. Behav. Neurosci. 115: 468-476.

Crawley, J.N. 1999. Behavioral phenotyping of transgenic and knockout mice: Experimental design and evaluation of general health, sensory functions, motor abilities, and specific behavioral tests. Brain Res. 835: $18-26$.

Danias, J., Lee, K.C., Zamora, M., Chen, B., Shen, F., Filippopoulos, T., Su, Y., Goldblum, D., Podos, S.M., and Mittag, T. 2003. Quantitative analysis of retinal ganglion cell (RGC) loss in aging DBA/2Nnia glaucomatous mice: comparison with RGC loss in aging C57BL/6 mice. Invest. Ophthalmol. Vis. Sci. 44: 5151-5162.

D'Hooge, R. and De Deyn, P.P. 2001. Applications of the Morris water maze in the study of learning and memory. Brain Res. Brain Res. Rev. 36: 60-90.

Fernandes, C., Paya-Cano, J.L., Sluyter, F., D'Souza, U., Plomin, R., and Schalkwyk, L.C. 2004. Hippocampal gene expression profiling across eight mouse inbred strains: Towards understanding the molecular basis for behavior. Eur. J. Neurosci. 19: 2576-2582.

Fox, G.B., LeVasseur, R.A., and Faden, A.I. 1999. Behavioral responses of C57BL/6, FVB/N, and 129/SvEMS mouse strains to traumatic brain injury: Implications for gene targeting approaches to neurotrauma. $J$. Neurotrauma 16: 377-389.

Garcia, M.F., Gordon, M.N., Hutton, M., Lewis, J., McGowan, E., Dickey, C.A., Morgan, D., and Arendash, G.W. 2004. The retinal degeneration (rd) gene seriously impairs spatial cognitive performance in normal and Alzheimer's transgenic mice. Neuroreport 15: $73-77$.

Gerlai, R. 1996. Gene-targeting studies of mammalian behavior: Is it the mutation or the background genotype? Trends Neurosci. 19: 177-181.

Guillot, P.V., Roubertoux, P.L., and Crusio, W.E. 1994. Hippocampal mossy fiber distributions and intermale aggression in seven inbred mouse strains. Brain Res. 660: 167-169.

Henderson, N.D., Turri, M.G., DeFrries, J.C., and Flint, J. 2004. QTL analysis of multiple behavioral measures of anxiety in mice. Behav. Genet. 34: 267-293.

Holmes, A., Wrenn, C.C., Harris, A.P., Thayer, K.E., and Crawley, J.N. 2002. Behavioral profiles of inbred strains on novel olfactory, spatial and emotional tests for reference memory in mice. Genes Brain Behav. 1: 55-69.

Jones, S.M., Jones, T.A., Johnson, K.R., Yu, H., Erway, L.C., and Zheng, Q.Y. 2006. A comparison of vestibular and auditory phenotypes in inbred mouse strains. Brain Res. 1091: 40-46.

Josselyn, S.A. 2005. What's right with my mouse model? New insights into the molecular and cellular basis of cognition from mouse models of Rubinstein-Taybi syndrome. Learn. Mem. 12: 111-119.

Kim, S., Lee, S., Ryu, S., Suk, J., and Park, C. 2002. Comparative analysis of the anxiety-related behaviors in four inbred mice. Behav. Processes 60: $181-190$.

Lalonde, R., Dumont, M., Paly, E., London, J., and Strazielle, C. 2004. Characterization of hemizygous SOD1/wild-type transgenic mice with the SHIRPA primary screen and tests of sensorimotor function and anxiety. Brain Res. Bull. 64: 251-258.

Leil, T.A., Ossadtchi, A., Cortes, J.S., Leahy, R.M., and Smith, D.J. 2002. Finding new candidate genes for learning and memory. J. Neurosci. Res. 68: 127-137.

McFadden, S.L., Ding, D., and Salvi, R. 2001. Anatomical, metabolic and genetic aspects of age-related hearing loss in mice. Audiology 40: $313-321$.

McFadyen, M.P., Kusek, G., Bolivar, V.J., and Flaherty, L. 2003. Differences among eight inbred strains of mice in motor ability and motor learning on a rotorod. Genes Brain Behav. 2: 214-219.

Mhyre, T.R., Chesler, E.J., Thiruchelvam, M., Lungu, C., Cory-Slechta, D.A., Fry, J.D., and Richfield, E.K. 2005. Heritability, correlations and in silico mapping of locomotor behavior and neurochemistry in inbred strains of mice. Genes Brain Behav. 4: 209-228.

Mineur, Y.S., Crusio, W.E., and Sluyter, F. 2004. Genetic dissection of learning and memory in mice. Neural Plast. 11: 217-240.

Moon, J.I., Kim, I.B., Gwon, J.S., Park, M.H., Kang, T.H., Lim, E.J., Choi, K.R., and Chun, M.H. 2005. Changes in retinal neuronal populations in the DBA/2J mouse. Cell Tissue Res. 320: 51-59.

Morris, R. 1984. Developments of a water-maze procedure for studying spatial learning in the rat. J. Neurosci. Methods 11: 47-60.

Nadler, J.J., Zou, F., Huang, H., Moy, S.S., Lauder, J., Crawley, J.N., Threadgill, D.W., Wright, F.A., and Magnuson, T.R. 2006. Large scale gene expression differences across brain regions and inbred strain correlate with behavioral phenotype. Genetics 174: 1229-1236.

Nguyen, P.V. and Gerlai, R. 2002. Behavioural and physiological characterization of inbred mouse strains: Prospects for elucidating the molecular mechanisms of mammalian learning and memory. Genes Brain Behav. 1: 72-81.

Nguyen, P.V., Abel, T., Kandel, E.R., and Bourtchouladze, R. 2000. Strain-dependent differences in LTP and hippocampus-dependent memory in inbred mice. Learn. Mem. 7: 170-179.

Owen, E.H., Logue, S.F., Rasmussen, D.L., and Wehner, J.M. 1997. Assessment of learning by the Morris water task and fear conditioning in inbred mouse strains and $\mathrm{F}_{1}$ hybrids: Implications of genetic background for single gene mutations and quantitative trait loci analyses. Neuroscience 80: 1087-1099.

Peirce, J.L., Chesler, E.J., Williams, R.W., and Lu, L. 2003. Genetic architecture of the mouse hippocampus: identification of gene loci with selective regional effects. Genes Brain Behav. 2: 238-252.

Pinto, L.H. and Enroth-Cugell, C. 2000. Tests of the mouse visual system. Mamm. Genome 11: 531-536.

Prusky, G.T., West, P.W.R., and Douglas, R.M. 2000a. Behavioral assessment of visual acuity in mice and rats. Vision Res. 40: 2201-2209.

Prusky, G.T., West, P.W.R., and Douglas, R.M. 2000b. Reduced visual acuity impairs place but not cued learning in the Morris water task. Behav. Brain Res. 116: 135-140.

Radcliffe, R.A., Lowe, M.V., and Wehner, J.M. 2000. Confirmation of contextual fear conditioning QTLs by short-term selection. Behav. Genet. 30: 183-191.

Robinson, L., Bridge, H., and Riedel, G. 2001. Visual discrimination learning in the water maze: a novel test for visual acuity. Behav. Brain Res. 119: 77-84.

Roullet, P. and Lassalle, J.M. 1995. Radial maze learning using exclusively distant visual cues reveals learners and nonlearners among inbred mouse strains. Physiol. Behav. 58: 1189-1195.

Royle, S.J., Collins, F.C., Rupniak, H.T., Barnes, J.C., and Anderson, R. 1999. Behavioural analysis and susceptibility to CNS injury of four inbred strains of mice. Brain Res. 816: 337-349.

Schellinck, H.M., Forestell, C.A., and Lolordo, V.M. 2001. A simple and reliable test of olfactory learning and memory in mice. Chem. Senses 26: $663-672$.

Schellinck, H.M., Arnold, A., and Refuse, V.F. 2004. Neural cell adhesion 
molecule (NCAM) null mice do not show a deficit in odour discrimination learning. Behav. Brain Res. 152: 327-334.

Schimanski, L.A. and Nguyen, P.V. 2004. Multidisciplinary approaches for investigating the mechanisms of hippocampus-dependent memory: A focus on inbred strains. Neurosci. Biobehav. Rev. 28: $463-483$

Schimanski, L.A. and Nguyen, P.V. 2005. Mouse models of impaired fear memory exhibit deficits in amygdalar LTP. Hippocampus 15: $502-517$.

Schmitt, U., Hiemke, C., Fahrenholz, F., and Schroeder, A. 2006. Over-expression of two different forms of the $\alpha$-secretase ADAM10 affects learning and memory in mice. Behav. Brain Res. 175: $278-284$.

Schoemaker, H., Nickolson, V.J., Kerbusch, S., and Crabbe, J.C. 1982 Synaptosomal uptake studies on recombinant mice; neurotransmitter interaction and behavioral correlates. Brain Res. 235: 253-264.

Serfilippi, L.M., Pallman, D.R., Gruebbel, M.M., Kern, T.J., and Spainhour, C.B. 2004. Assessment of retinal degeneration in outbred albino mice. Comp. Med. 54: 69-76.

Sik, A., van Nieuwehuyzen, P., Prickaerts, J., and Blokland, A. 2003. Performance of different mouse strains in an object recognition task. Behav. Brain Res. 147: 49-54.

Smith, D.R., Striplin, C.D., Geller, A.M., Mailman, R.B., Drago, J., Lawler, C.P., and Gallagher, M. 1998. Behavioral assessment of mice lacking $\mathrm{D}_{1 \mathrm{~A}}$ dopamine receptors. Neuroscience 86: 135-146.

Stasko, M.R. and Costa, A.C.S. 2004. Experimental parameters affecting the Morris water maze performance of a mouse model of Down syndrome. Behav. Brain Res. 154: 1-17.

Steinberger, D., Reynolds, D.S., Ferris, P., Lincoln, R., Datta, S., Stanley, J., Paterson, A., Dawson, G.R., and Flint, J. 2003. Genetic mapping of variation in spatial learning in the mouse. J. Neurosci. 15: $2426-2433$.

Tarantino, L.M., Gould, T.J., Druhan, J.P., and Bucan, M. 2000. Behavior and mutagenesis screens: The importance of baseline analysis of inbred strains. Mamm. Genome 11: 555-564.

Thifault, S., Lalonde, R., Sanon, N., and Hamet, P. 2002. Comparisons between $\mathrm{C} 57 \mathrm{BL} / 6 \mathrm{~J}$ and $\mathrm{A} / \mathrm{J}$ mice in motor activity and coordination, hole-poking, and spatial learning. Brain Res. Bull. 58: 213-218.

Tonegawa, S., Nakazawa, K., and Wilson, M.A. 2003. Genetic neuroscience of mammalian learning and memory. Philos. Trans. $R$.
Soc. Lond. B Biol. Sci. 358: 787-795.

Upchurch, M. and Wehner, J.M. 1988. Differences between inbred strains of mice in Morris water maze performance. Behav. Genet. 18: $55-68$.

van Gaalen, M.M. and Steckler, T. 2000. Behavioral analysis of four mouse strains in an anxiety test battery. Behav. Brain Res. 115: $95-106$.

Voikar, V., Koks, S., Vasar, E., and Rauvala, H. 2001. Strain and gender differences in the behavior of mouse lines commonly used in transgenic studies. Physiol. Behav. 72: 271-281.

Wahlsten, D. and Andison, M. 1991. Patterns of cerebellar foliation in recombinant inbred mice. Brain Res. 557: 184-189.

Wahlsten, D., Metten, P., and Crabbe, J.C. 2003. Survey of 21 inbred mouse strains in two laboratories reveals that BTBR $/+t f / t f$ has severely reduced hippocampal commissure and absent corpus callosum. Brain Res. 971: 47-54.

Wahlsten, D., Bachmanov, A., Finn, D.A., and Crabbe, J.C. 2006. Stability of inbred mouse strain differences in behavior and brain size between laboratories and across decades. Proc. Natl. Acad. Sci. 103: $16364-16369$.

Wolfer, D.P., Stagljar-Bozicevic, M., Errington, M.L., and Lipp, H. 1998. Spatial memory and learning in transgenic mice: fact or artifact? News Physiol. Sci. 13: 118-123.

Wong, A.A. and Brown, R.E. 2004. The influence of visual ability on the behaviour of 13 strains of mice in a battery of tests. Abstract no. 83.7. Society for Neuroscience 2004, San Diego, CA.

Wong, A.A. and R.E. Brown. 2006a. Age-related changes in visual acuity, learning and memory in C57BL/6J and DBA/2J mice. Neurobiol. Aging. doi:10.1016/j.neurobiolaging.2006.07.023.

Wong, A.A. and Brown, R.E. 2006b. Visual detection, pattern discrimination and visual acuity in 14 strains of mice. Genes Brain Behav. 5: 389-403.

Yoshiki, A. and Moriwaki, K. 2006. Mouse phenome research: Implications of genetic background. ILAR J. 47: 94-102.

Zhou, X., Li, F., Kong, L., Tomita, H., Li, C., and Cao, W. 2005. Involvement of inflammation, degradation and apoptosis in a mouse model of glaucoma. J. Biol. Chem. 280: 31240-31248.

Received November 14, 2006; accepted in revised form January 11, 2007.
144 Learning \& Memory www.learnmem.org 


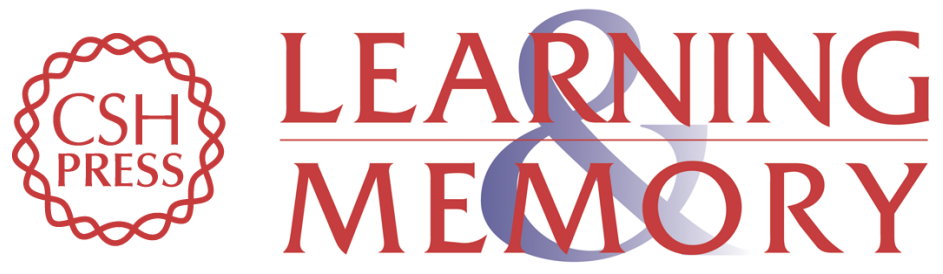

\section{The influence of visual ability on learning and memory performance in 13 strains of mice}

Richard E. Brown and Aimée A. Wong

Learn. Mem. 2007, 14:

Access the most recent version at doi:10.1101//m.473907

References This article cites 69 articles, 7 of which can be accessed free at: http://learnmem.cshlp.org/content/14/3/134.full.html\#ref-list-1

License

Email Alerting Receive free email alerts when new articles cite this article - sign up in the box at the Service top right corner of the article or click here. 